\title{
Long-Term Impact of Conservation Agriculture on Chemical Properties of Soil
}

\author{
Dipti Kumari ${ }^{1}$, Sunil Kumar ${ }^{1 *}$, Hena Parveen ${ }^{1}$, \\ Amit Kumar Pradhan ${ }^{1}$, Sanjay Kumar ${ }^{2}$ and Ragini Kumari ${ }^{1}$ \\ ${ }^{1}$ Department of Soil Science and Agricultural Chemistry, Bihar Agricultural University, \\ Sabour, Bhagalpur 813210 (Bihar), India \\ ${ }^{2}$ Department of Agronomy, Bihar Agricultural University, Sabour, \\ Bhagalpur 813210 (Bihar), India \\ *Corresponding author
}

\begin{abstract}
A B S T R A C T

\begin{tabular}{|l|}
\hline Key w or d s \\
Zero tillage, \\
Conventional \\
tillage, Organic \\
carbon, CEC, \\
Sulphur
\end{tabular}

A long-term field experiment was carried out in alluvial soil with conservation agriculture practices like Zero tillage (ZT), Permanent bed (PB) and Conventional tillage (CT) to see the impact on Physico-chemical Properties of soil under rice based cropping systems. After completion of 7th cycle of experiment (2018), soil samples were collected from each plot and analysis processes were executed. The results obtained from the study show that the conservation agricultural practices increased the organic carbon 0.47 to $0.71 \%$, cation exchange capacity 9.76 to $13.04\left[\mathrm{cmol}\left(\mathrm{p}^{+}\right) \mathrm{kg}^{-1}\right.$ ], available- $\mathrm{N} 150.52$ to $175.67 \mathrm{~kg} / \mathrm{ha}$ available $\mathrm{P}_{2} \mathrm{O}_{5} 150.52$ to $175.67 \mathrm{~kg} / \mathrm{ha}$, available $\mathrm{K}_{2} \mathrm{O} 202.40$ to $245.63 \mathrm{~kg} / \mathrm{ha}$ and available $\mathrm{S} 14.66$ to $22.84 \mathrm{mg} / \mathrm{kg}$ of soil. It was further observed that after 7 years of experimentation, a build-up of organic carbon upto $30 \%(0.69 \%)$ and $26 \%(0.67 \%)$ from the initial value $(0.53 \%)$ due to zero tillage and permanent bed respectively were observed. Among the cropping systems, Rice-Lentil system sustained the soil physico-chemical properties to a greater extent compared to Rice-Wheat and Rice-Maize systems. Retention of crop residue and minimum disturbance of surface soil under conservation agriculture increases the organic matter content leading to enhanced crop nutrition and sustain the soil health.
\end{abstract}

\section{Introduction}

Conservation Agriculture (CA) originally developed in the United States of America (Thierfelder et al., 2013; Thierfelder and Wall, 2009; Lahmar, 2008) and reducing land degradation and production costs was later introduced to Europe and Africa (Lahmar, 2008; FAO, 2008; Van Wie et al., 2013) Globally, CA is being practiced on about 125 $\mathrm{M}$ ha The major countries are USA(26.5 M ha), Brazil (25.5 M ha), Argentina (25.5 M ha), Canada (13.5 M ha) and Australia (17.0 M ha). In India adoption is still in the initial 
phases. Over the past few years, adoption of zero tillage and CA has expanded to cover about 1.5 million hectares (Jat et al., 2012). CA is more sustainable agriculture production practice (Wall, 2007). conservation tillage to give the maximum benefits (Hobbs et al., 2008) and it combine the following basic principles (Verhulst et al., 2010 and Jat et al., 2012):. to bring positive changes in the physical, chemical and biological properties of a soil (Bescansa et al., 2006), Improved soil fertility and structure (Choudhary et al., 2018 ,Obour et al., 2017 and Yadav et al., 2017), providing a suitable growing environment to support high yields (Wang and Li, 2014; Cai et al., 2014). Frequency and intensity of tillage had significant influence on disintegration and decomposition of organic matter including residues (Singh and Ladha, 2004). Under no till and permanent raised beds, higher total nitrogen was recorded (Govaerts et al., 2007 Thomas et al., 2007 and Graham et al., 2002) and nitrogen mineralization (Kristensen et al., 2000).

The available $\mathrm{P}$ under no till with straw retention (NTSC) was $97.5 \%$ higher in the $0-5$ $\mathrm{cm}$ layer (Wang, 2008). Various studied, higher extractable $\mathrm{P}$ levels in no tillage than in tilled soil (Duiker and Beegle 2006, Franzluebbers and Hons, 1996; Edwards et al., 1992; and Follett and Peterson, 1988) and this is due to reduced mixing of the fertilizer $\mathrm{P}$ with the soil, leading to lower P-fixation. Reduces loss of nutrients, environmental pollution and which reduces a serious health hazard (Sidhu et al., 2007). Permanent raised beds with residue retention had higher $\mathrm{K}$ concentration in surface layer, Govaerts et al., (2007). In no till or minimum till system, the relatively immobile nutrients $\mathrm{P}$ and $\mathrm{K}$ remains concentrated in the upper soil layer of minimum tilled plots (Shear and Moschler, 1969; Triplett and Van Doren, 1969; Fink and Wesley, 1974; and Ismail et al., 1994).

\section{Materials and Methods}

\section{Site and soil characteristics}

A long-term experimental field was initiated in kharif 2011 on fine sandy loam soil at Bihar Agricultural University Research Farm, Sabour (Latitude $25^{\circ} 23^{\prime} \mathrm{N}$, longitude $87^{\circ} 07^{\prime} \mathrm{E}$ and altitude $37.19 \mathrm{~m}$ M.S.L.). It was carried out in 2018 and is a part of the ongoing Conservation Agriculture experiment on "Effect of rice establishment techniques on crop yield of different rice based cropping systems. The site is characterized by the aridity, semi-arid monsoon climate, with extreme temperatures ranges between 28 to $44^{\circ} \mathrm{C}$, whereas, in winter temperature falls down to as low as $3^{0} \mathrm{C}$.The average rainfall varies between 400 to $500 \mathrm{~mm}$, Wells are the only source of irrigation and water table is quite deep (about 55-60metres). The experimental soil had $\mathrm{pH} 7.36$, EC $0.30 \mathrm{dSm}$ ${ }^{1}$, organic carbon $0.53 \%$, available N 160.16, $\mathrm{P}_{2} \mathrm{O}_{5} \quad 26.68$ and $\mathrm{K}_{2} \mathrm{O} \quad 221.60 \mathrm{~kg} / \mathrm{ha}$, respectively.

\section{Experimental details}

The treatments consists of three tillage practices Zero tillage (ZT), Permanent bed (PB), Conventional Tillage (CT) and three rice based cropping systems: Rice-Wheat (RW), Rice-Maize (RM) and Rice-Lentil (RL). The study was made in split plot design with three replications.

Full dose of $\mathrm{P}$ and $\mathrm{K}$ were applied as basal dose and $\mathrm{N}$ in three split doses through single super phosphate, muriate of potash and urea, respectively. Since the initiation of the experiment, Rice is being grown continuously during Kharif through direct seeding in Zero Tillage (ZT) and Permanent Bed (PB) plots, and on the same date rice seeds are sown in the nursery bed for conventional/puddled method of establishment. Wheat and Lentil 
are grown during Rabi in rows, while Maize was sown through dibbler.

\section{Soil sampling and processing}

Soil samples from the surface $(0-15 \mathrm{~cm})$ were collected from all the 27 plots after completion of seven years of the experiment in 2018. These samples were air dried and processed to pass through $2 \mathrm{~mm}$ sieve as usual and stored in polyethylene bags for analysis. The soil water suspension (EC) and Soil $\mathrm{pH}$ ware measured with a electrical conductivity meter and $\mathrm{pH}$ meter, soil to water ratio of 1:2.5 by Jackson (1973). Easily oxidizable organic carbon of soil was estimated by Walkley and Black, 1934 method. Available $\mathrm{N}$ was estimated by alkaline potassium permanganate solution and determining the ammonia liberated (Subbiah and Asija, 1956). Available Phosphorus was extracted with $0.5 \mathrm{M}$ Sodium bi-carbonate at pH 8.5 (Olsen et al., 1965). Available K was extracted with $1 \mathrm{~N}$ ammonium acetate and measured with a flame photometer (Hanway and Heidel, 1952). Available sulphur content was determined Turbidimetrically (Tandon, 1991). CEC was determined by $\mathrm{NH}_{4} \mathrm{OAC}$ method (Jackson, 1973).

\section{Results and Discussion}

\section{Soil Reaction (pH)}

Soil $\mathrm{pH}$ varied from 7.19 to 7.37 in establishment methods (Table 1). In Zero tillage (7.19) method was found to have slightly lower $\mathrm{pH}$ compared to conventional tillage (7.37). Different cropping system, soil $\mathrm{pH}$ varied from 7.24 to 7.28 (Table 2). Rice Lentil (7.24) cropping system was found to have slightly lower $\mathrm{pH}$ than rice- wheat (7.28). The effect of crop establishment methods and rice based cropping systems were found to be statistically non-significant which varied from 7.14 to 7.38 (Table 3 ). Soil
$\mathrm{pH}$ was observed to be lower under conservation agriculture as compared to conventional method which might be due to direct incorporation of crop residues in the soil under conservation agriculture and the subsequent decomposition of these crop residues might have released various organic acids which would have resulted in decrement of soil $\mathrm{pH}$ under conservation agriculture. Similar result was observed by Yadav et al., (2017) who stated in their work that conservation agriculture has got the potential to improve physical, chemical and biological characteristics of the soil and Govaerts et al., (2006) stated that non-significant effect was found for soil $\mathrm{pH}$ under conservation agriculture.

\section{Electrical Conductivity (EC)}

The EC ranged between 0.26 to $0.31 \mathrm{dSm}^{-1}$ (Table 3) due to interaction effect of establishment methods (T) and cropping systems (S) and was found statistically nonsignificant. Among the three crop establishment methods, lowest value was found to be 0.28 under ZT as compared to PB and CT which are statistically at par with each other (Table 1). EC value also declined from 0.29 to 0.28 (Table 2) due to Rice-Lentil (RL) cropping system as compared to Rice-Wheat (RW) and Rice-Maize (RM). The EC of conventional method was found to have higher value than Zero Tillage which might be due to higher pore size and porosity of the soil under Zero Tillage which would have led to leaching down of the basic cations.

\section{Soil organic carbon}

Organic Carbon (OC) content of the soil under conservation agriculture ranged from 0.47 to $0.71 \%$ (Table 3) due to interaction effect of crop establishment methods (T) and rice based cropping systems (S) and was found to be statistically non-significant. 
Among the three crop establishment methods, minimum OC content was found to be $0.49 \%$ in CT which increased significantly to $0.67 \%$ in PB and $0.69 \%$ in ZT (Table 1). Zero tillage had significant effect on soil organic carbon content as compared to conventional tillage and which was found statistically at par with permanent bed. It is apparently visualized from the Figure 1 that there was an increase of $30.19 \%$ and $26.42 \%$ under ZT (Zero Tillage) and PB (Permanent Bed) respectively from initial $\mathrm{OC}$ values i.e. $0.53 \%$ due to different treatment combinations. Among the three different cropping systems, it was observed that OC content increased up to (Table 2) $0.63 \%$ under Rice-Maize which was superior to $0.62 \%$ in Rice-Wheat and $0.61 \%$ in Rice-Lentil cropping system but was statistically non-significant. These results are in accordance with Paustian et al., (1997) who reported that tillage affects the equilibrium of soil carbon balance through incorporation of crop residues and through physical disturbance and mixing of soil and the exposed aggregates. Lower amount of organic carbon was found under conventional method which was similar to the result found by Freibauer et al., (2004) and Matos et al., (2011).

\section{Available nitrogen}

The data ranged from 150.52 to $175.67 \mathrm{~kg}$ $\mathrm{ha}^{-1}$ due to different treatment combinations (Table 3) and the interaction effect of establishment methods and cropping system were found statistically non-significant. Among the three different crop establishment methods, highest was recorded to be 171.43 $\mathrm{kg} \mathrm{ha}^{-1}$ under Zero Tillage and lowest value was recorded as $156.10 \mathrm{~kg} \mathrm{ha}^{-1}$ under Conventional Tillage. Maximum Available N content was found to be $170.04 \mathrm{~kg} \mathrm{ha}^{-1}$ under Rice-Lentil cropping system and lowest to be $160.28 \mathrm{~kg} \mathrm{ha}^{-1}$ under Rice- Maize cropping System (Table 2) Rice-Wheat (R-W) and
Rice-Maize (R-M) cropping system were statistically similar with respect to available Nitrogen content of soil. It might be due to larger addition of crop residues and less soil disturbances. Increased tillage practices under conventional method make the soil susceptible to erosion of nitrogen and hence conventional tillage has lowest available $\mathrm{N}$. These results are in agreement with Carter et al., (1998). Similar observations on the effect of tillage and residue management have been made by several workers (Dupreez et al., 2001, Govaerts et al., 2007 and Peng et al., 2008).

\section{Available Phosphorus}

Different treatment combinations and the interaction effect of establishment methods and cropping system were found statistically non-significant, the data ranged from 24.01 to $34.85 \mathrm{~kg} \mathrm{ha}^{-1}$ (Table 3). The maximum available $\mathrm{P}_{2} \mathrm{O}_{5}$ content $(34.85 \mathrm{~kg} / \mathrm{ha})$ was noted with treatment ZT-RL combination while minimum $(24.01 \mathrm{~kg} / \mathrm{ha})$ available $\mathrm{P}_{2} \mathrm{O}_{5}$ was noted in CT-RM treatment combination. Among the cropping systems, maximum available $\mathrm{P}_{2} \mathrm{O}_{5}$ content was recorded to be $32.81 \mathrm{~kg} / \mathrm{ha}$ under Rice-Lentil cropping system followed by 29.86 and $28.41 \mathrm{~kg} / \mathrm{ha}$ soil due to Rice-Wheat and Rice-Maize cropping system, respectively (Table 2). RiceLentil cropping system was significantly superior over Rice-Wheat and Rice-Maize cropping system and Rice-Wheat and RiceMaize cropping system was statistically at par with each other. Among the three different crop establishment methods, highest was recorded to be $32.64 \mathrm{~kg} \mathrm{ha}^{-1}$ under Zero Tillage and lowest value was recorded as $26.42 \mathrm{~kg} \mathrm{ha}^{-1}$ under Conventional Tillage (Table 1). The amount of available $\mathrm{P}_{2} \mathrm{O}_{5}$ was found higher under conservation agriculture as compared to conventional tillage which might be due to larger addition of crop residues in conservation agriculture which 
increases $\mathrm{P}$ solubilisation and reduce $\mathrm{P}$ fixation. These results are in agreement with Kumar et al., (2008) who reported increment in available $\mathrm{P}_{2} \mathrm{O}_{5}$ in the soil with incorporation of crop residues. On the other hand, Roldan et al., (2007) reported that available $\mathrm{P}$ was not affected by different tillage systems and crop rotations.

\section{Available potassium}

The data ranged from 202.40 to $245.63 \mathrm{~kg} / \mathrm{ha}$ due to different treatment combinations (Table 3) and the interaction effect of establishment methods and cropping systems were found to be statistically non-significant. Among the three establishments methods, maximum content of available $\mathrm{K}_{2} \mathrm{O}$ (236.03 $\mathrm{kg} / \mathrm{ha}$ ) was noted under Zero Tillage treatment and minimum content of available $\mathrm{K}_{2} \mathrm{O} \quad(213.59 \mathrm{~kg} / \mathrm{ha})$ was found under Conventional Tillage (Table 1). The effects of different establishment methods on available $\mathrm{K}_{2} \mathrm{O}$ content of soil were statistically nonsignificant. The results further indicated that cropping systems have statistically significant effect on available $\mathrm{K}_{2} \mathrm{O}$. Highest available $\mathrm{K}_{2} \mathrm{O}$ content was recorded to be $239.01 \mathrm{~kg} / \mathrm{ha}$ under Rice-Lentil cropping system which was significantly superior over Rice-Maize cropping system (Table 2). Rice-Wheat cropping system was statistically at par with Rice-Maize cropping system. This result was in agreement with the findings of MartinRueda et al., (2007) who reported that extractable $\mathrm{K}$ was higher for no tillage in the surface layer $(0-15 \mathrm{~cm})$ as compared to conventional tillage. Similar result was in accordance with the findings of Carter et al., (2002) who noted non-significant differences among treatments and Yadav et al., (2016) reported that highest amount of $\mathrm{K}(203.1 \mathrm{~kg}$ $\mathrm{ha}^{-1}$ ) in $0-15 \mathrm{~cm}$ soil surface was recorded under PB planting while minimum amount of available $\mathrm{K}$ were observed under $\mathrm{CT}$ after seven years of CA. Rice-Lentil cropping system was found to be significantly superior over both Rice-Wheat and Rice-Maize cropping system having maximum content under Rice-Lentil cropping system.

\section{Available sulphur}

The data ranged from 14.75 to $18.25 \mathrm{mg} / \mathrm{kg}$ (Table 3) due to different treatment combinations and the interaction effect of establishment methods and cropping systems were found to be statistically non-significant. Among different crop establishment methods, highest content of available S $19.76 \mathrm{mg} / \mathrm{kg}$ was recorded under Zero Tillage which was followed by $18.07 \mathrm{mg} / \mathrm{kg}$ under Permanent Bed and lowest value was $15.25 \mathrm{mg} / \mathrm{kg}$ recorded under Conventional Tillage (Table 1). The effect of different establishment methods on available $S$ content of the soil was found to be statistically significant. Rice based cropping systems was found to be statistically significant with highest value of $19.74 \mathrm{mg} / \mathrm{kg}$ recorded under Rice-Lentil cropping system which was significantly superior over Rice-Maize cropping system which was noted to be $16.59 \mathrm{mg} / \mathrm{kg}$ followed by Rice-Wheat cropping system with a value of $16.59 \mathrm{mg} / \mathrm{kg}$ (Table 2). These results are in agreement with the findings of Sarkar et al., (1998) who reported that incorporation of various organic residues like compost, FYM and crop residues can enhance the supply of adequate quantity of sulphur to crops. Rice Lentil cropping system was found to be statistically superior over both Rice-Wheat and Rice-maize cropping systems.

\section{Cation Exchange Capacity (CEC)}

It ranged from 9.76 to $13.04 \mathrm{cmol}\left(\mathrm{p}^{+}\right) \mathrm{kg}^{-1}$ (Table 3) due to interaction effect of different establishment methods (T) and cropping systems (S) but results were observed to be non-significant. Crop establishment methods (Table 1) increased CEC significantly from 10.33 to $11.92 \mathrm{cmol}(\mathrm{p}+) \mathrm{kg}^{-1}$ (Table 1). 
Table.1 Effect of establishment method on nutrient of soil under conservation agriculture

\begin{tabular}{|c|c|c|c|c|c|c|c|c|}
\hline & pH & $\begin{array}{c}\mathrm{EC} \\
\left(\mathrm{dSm}^{-1}\right)\end{array}$ & $\begin{array}{l}\text { O.C. } \\
(\%)\end{array}$ & $\begin{array}{c}\text { CEC [cmol } \\
\left.\left(p^{+}\right) \mathrm{kg}^{-1}\right]\end{array}$ & $\begin{array}{l}\text { Avail.N } \\
\text { (kg/ha) }\end{array}$ & $\begin{array}{c}\text { Avail. } \mathbf{P}_{2} \mathbf{O}_{5} \\
(\mathrm{~kg} / \mathrm{ha})\end{array}$ & $\begin{array}{c}\text { Avail. } \mathrm{K}_{2} \mathrm{O} \\
\text { (kg/ha) }\end{array}$ & $\begin{array}{l}\text { Avail. S } \\
\text { (mg/kg) }\end{array}$ \\
\hline ZT & 7.19 & 0.28 & 0.69 & 11.92 & 171.43 & 32.54 & 236.03 & 19.76 \\
\hline PB & 7.27 & 0.29 & 0.67 & 11.41 & 167.25 & 32.12 & 231.90 & 18.07 \\
\hline CT & 7.37 & 0.29 & 0.49 & 10.33 & 156.10 & 26.42 & 213.59 & 15.71 \\
\hline $\operatorname{SEm}( \pm)$ & 0.07 & 0.01 & 0.02 & 0.27 & 4.37 & 0.78 & 9.16 & 0.36 \\
\hline $\begin{array}{c}\text { LSD } \\
(\mathbf{P}=0.05)\end{array}$ & NS & NS & 0.08 & 1.04 & $\mathrm{NS}$ & 3.06 & NS & 1.43 \\
\hline
\end{tabular}

Table.2 Effect of cropping system on nutrient of soil under conservation agriculture

\begin{tabular}{|c|c|c|c|c|c|c|c|c|}
\hline & pH & $\begin{array}{c}\mathrm{EC} \\
\left(\mathrm{dSm}^{-1}\right)\end{array}$ & $\begin{array}{l}\text { O.C. } \\
(\%)\end{array}$ & $\begin{array}{c}\text { CEC [cmol } \\
\left.\left(\mathrm{p}^{+}\right) \mathrm{kg}^{-1}\right]\end{array}$ & $\begin{array}{c}\text { Avail. N } \\
\text { (kg/ha) }\end{array}$ & $\begin{array}{c}\text { Avail. } \mathrm{P}_{2} \mathrm{O}_{5} \\
\text { (kg/ha) }\end{array}$ & $\begin{array}{c}\text { Avail. } \mathrm{K}_{2} \mathrm{O} \\
\text { (kg/ha) }\end{array}$ & $\begin{array}{l}\text { Avail. S } \\
\text { (mg/kg) }\end{array}$ \\
\hline R-W & 7.28 & 0.29 & 0.62 & 11.00 & 164.47 & 29.86 & 223.57 & 17.24 \\
\hline R-M & 7.32 & 0.29 & 0.63 & 10.51 & 160.28 & 28.41 & 218.94 & 16.59 \\
\hline R-L & 7.24 & 0.28 & 0.61 & 12.15 & 170.04 & 32.81 & 239.01 & 19.74 \\
\hline $\operatorname{SEm}( \pm)$ & 0.04 & 0.01 & 0.02 & 0.24 & 6.36 & 0.78 & 4.34 & 0.41 \\
\hline$\underset{(P=0.05)}{\text { LSD }}$ & NS & NS & NS & 0.74 & NS & 3.06 & 13.37 & 1.27 \\
\hline
\end{tabular}

Table.3 Effect of establishment methods and cropping systems of soil under Conservation agriculture

\begin{tabular}{|c|c|c|c|c|c|c|c|c|}
\hline & pH & $\begin{array}{c}\mathrm{EC} \\
\left(\mathrm{dSm}^{-1}\right)\end{array}$ & $\begin{array}{l}\text { O.C. } \\
(\%)\end{array}$ & $\begin{array}{c}\text { CEC } \\
{\left[\mathrm{cmol}^{+}\left(\mathrm{p}^{+}\right)\right.} \\
\left.\mathrm{kg}^{-1}\right]\end{array}$ & $\begin{array}{c}\text { Avail. N } \\
\text { (kg/ha) }\end{array}$ & $\begin{array}{c}\text { Avail.P. } \\
\text { (kg/ha) }\end{array}$ & $\begin{array}{c}\text { Avail. } K_{2} 0 \\
\text { (kg/ha) }\end{array}$ & $\begin{array}{l}\text { Avail. S } \\
\text { (mg/kg) }\end{array}$ \\
\hline ZT-RW & 7.21 & 0.29 & 0.69 & 11.68 & 171.44 & 32.29 & 232.77 & 18.54 \\
\hline ZT-RM & 7.23 & 0.29 & 0.71 & 11.03 & 167.25 & 30.47 & 229.68 & 17.99 \\
\hline ZT-RL & 7.14 & 0.26 & 0.67 & 13.04 & 175.67 & 34.85 & 245.63 & 22.84 \\
\hline PB-RW & 7.28 & 0.31 & 0.67 & 11.17 & 167.25 & 32.03 & 229.50 & 17.33 \\
\hline PB-RM & 7.34 & 0.30 & 0.70 & 10.73 & 163.07 & 30.75 & 224.73 & 17.13 \\
\hline PB-RL & 7.21 & 0.28 & 0.65 & 12.32 & 171.43 & 33.57 & 241.47 & 19.76 \\
\hline CT-RW & 7.35 & 0.30 & 0.49 & 10.16 & 154.71 & 25.25 & 208.43 & 15.87 \\
\hline CT-RM & 7.38 & 0.30 & 0.47 & 9.76 & 150.52 & 24.01 & 202.40 & 14.66 \\
\hline CT-RL & 7.38 & 0.28 & 0.50 & 11.08 & 163.07 & 30.00 & 229.93 & 16.61 \\
\hline $\operatorname{SEm}( \pm)$ & 0.13 & 0.01 & 0.03 & 0.42 & 11.02 & 1.87 & 7.51 & 0.72 \\
\hline 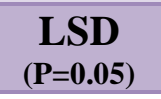 & NS & NS & NS & NS & NS & NS & NS & $\mathrm{NS}$ \\
\hline
\end{tabular}


Fig.1 Soil physico-chemical properties as influenced by conservation agriculture after 7 years of experimentation

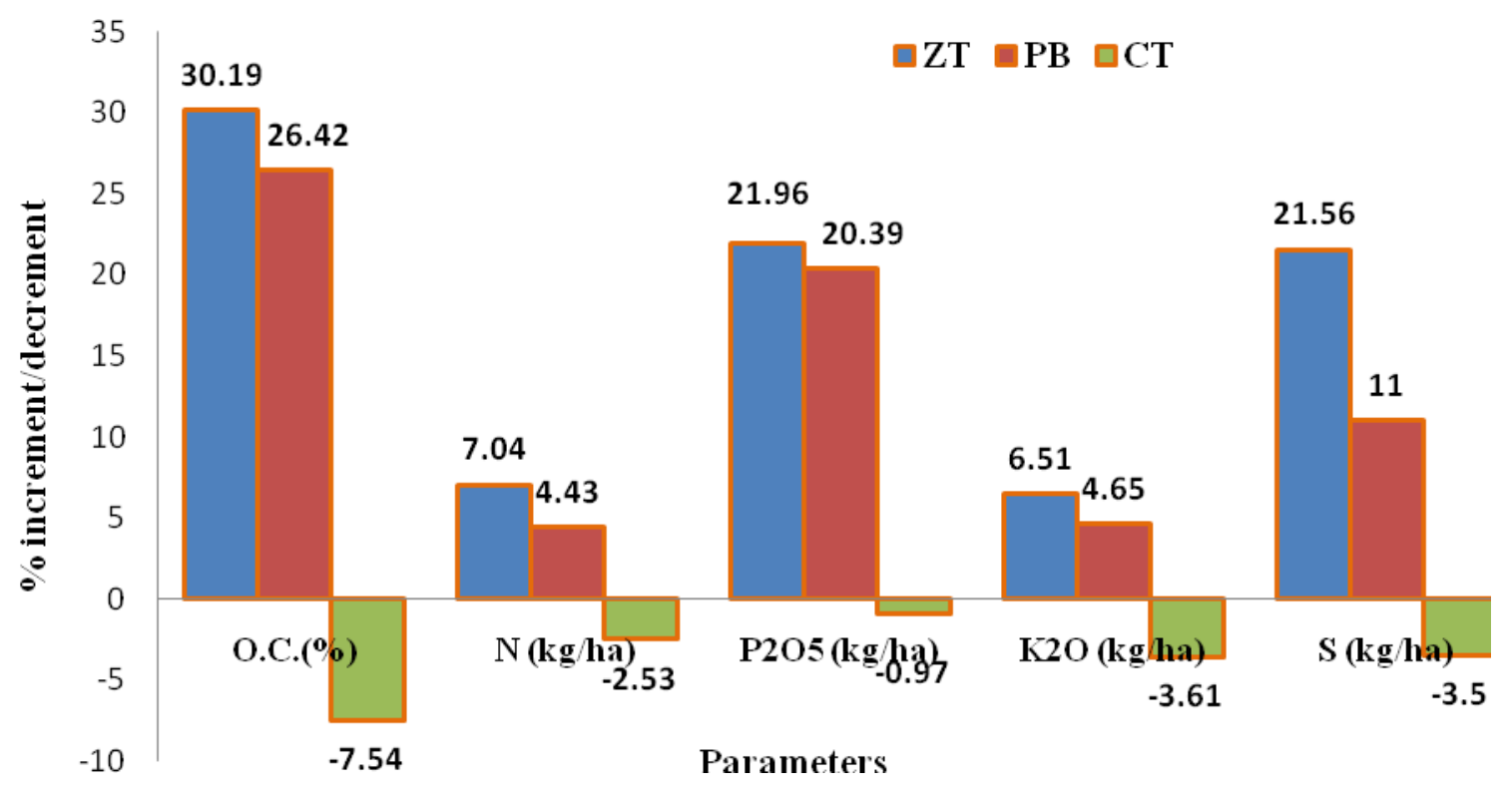

Zero tillage (ZT) was observed to be statistically at par with permanent bed (PB) and significantly superior over conventional tillage (CT). Rice based cropping systems increased CEC significantly from 10.51 to $12.51 \mathrm{cmol}(\mathrm{p}+) / \mathrm{kg}$ (Table 2) and Rice-Lentil cropping system was found to be superior over Rice-Maize cropping system. Highest value was recorded under zero tillage and rice-lentil cropping systems under different crop establishment methods and rice based cropping systems, respectively. This might be due to presence of high organic matter which in turn leads to presence of phenolic and carboxylic acids and which increases negative charge due to lower dissociation of constant. Burle et al., (1997) studied the effect of cropping systems on soil chemical parameters and they observed that increase in soil CEC may occur in no-till systems with legumes because of larger addition of organic residues which increases soil acidification through carbon and nitrogen cycles. These results are also in accordance with the findings of Sharma et al., (1988) and Dasappagol et al.,
(2017).

Conclusion can be drawn from the above discussion that the organic carbon, CEC, available $\mathrm{P}_{2} \mathrm{O}_{5}$ and Sulphur content of soil were significantly build up after 7 years of experimentation due to zero tillage and permanent bed establishment methods as well as rice lentil cropping system under conservation agriculture which might be due to the accumulation of higher amount of organic carbon in surface soils that has resulted from its recycling over the years by subsequent crop residue accumulation under zero tillage and permanent bed technique. Thus, CA-based management practices are superior and sustainable for long-term crop production that maintains the soil health as compared to conventional tillage practices.

\section{References}

Bescansa, P., Imaz, M. J., Virto, I., Enrique, A. and Hoogmoed, W.B. (2006). Soil water retention as affected by tillage and residue management in semi-arid Spain. Soil and 
Tillage Research 87, 19-27.

Burle ML, Mielniczuk J, Focchi S (1997) Effect of cropping systems on soil chemical characteristics, with emphasis on soil acidification. Plant and Soil, 190:309-316

Cai, H.G., Ma, W., Zhang, X.Z., Ping, J.Q., Yan, X.G., Liu, J.Z., Yuan, J.C., Wang, L.C., Ren, J., (2014). Effect of subsoil tillage depth on nutrient accumulation, root distribution, and grain yield in spring maize. Crop J. 2, 297.

Carter, M.R, EG, Angers D.A, Donald R.G, Bolinder M.A. (1998) Organic C and N storage and organic $\mathrm{C}$ fractional in adjacent cultivated and forested soils of eastern Canada. Soil and Tillage Research. 47:253261.

Carter, M. R., Saderson, J. B., Ivany, J. A. and White, R. P. (2002) Influence of rotation and tillage on forage maize productivity, weed species and soil of a fine sandy loam in the humid climate of Atlantic, Canada. Soil and Tillage Research 67, 85-98.

Choudhary M., Jat H. S., Datta A., Yadav A. K., Sapkota T. B., Mondal S., Meena R. P., Sharma P. C. and Jat M. L. (2018). Sustainable intensification influences soil quality, biota, and productivity in cerealbased agroecosystems. Appl. Soil Ecol. 126:189-198.

Dasappagol A, Bellakki M, Ravi M, Kuchanur P, Jat M (2017) Distribution of Zinc fractions in surface Alfisol after five years of Conservation agriculture practices in Rainfed Pigeonpea. International Journal of Chemical Studies, 5(1):227-232

Duiker, S.W. and Beegle, D. B.(2006). Soil fertility distributions in long-term no-till, chisel/disk and moldboard plow/disk systems. Soil and Tillage Research 88:3041.

DuPreeze CC, Steyn JT, Kotze E (2001) Long term effects of wheat residue management on some fertility indicators of a semi-arid Plinthosol. Soil and Tillage Research, 63:25-33.

Edwards, J. H., Wood, C. W., Thurlow, D. L. and M. E. (1992). Tillage and crop-rotation effects on fertility status of a Hapludult Soil. Soil Sci. Soc. Am. J. 56:1577-1582.

FAO. (2008). Investing in Sustainable
Agricultural Intensification. The Role of Conservation Agriculture, A Framework for Action, Food and Agriculture Organization of the United Nations Rome, Italy 10 August 2008.

Fink, R.J. and Wesley, D. (1974). Corn yield as affected by fertilization and tillage systems. Agron. J. 66: 70-71

Follett, R.F. and Peterson, G. A. (1988). Surface soil nutrient distribution as affected by wheat-fallow tillage systems. Soil Sci. Soc. Am. J. 52:141-147.

Franzluebbers, A.J. and Hons, F. M. (1996). Soilprofile distribution of primary and secondary plant available nutrients under conventional and no tillage. Soil Till. Res. 39:229-239.

Freibauer A, Rounsevell MDA, Smith P, Verhagen J. Carbon sequestration in the agricultural soils of Europe. Geoderma. 2004; 122:1-23.

Govaerts, B., Sayre, K. D., Lichter, K., Dendooven, L. and Deckers, J. (2007). Influence of permanent raised bed planting and residue management on physical and chemical soil quality in rain fed maize/wheat systems. Plant Soil 291:39-54.

Graham, M.H., Haynes, R. J. and Meyer, J.H. (2000). Soil organic matter content and quality: effects of fertilizer applications, burning and trash retention on a long-term sugarcane experiment in South Africa. Soil Biol. Biochem. 34:93-102.

Hanway, J.J., and Heidel, H. (1952). Soil analysis methods as used in Iowa state college soil testing laboratory. Iowa State College of Agriculture, Vol. 57: 1-3.

Hobbs P R, Sayre K and Gupta R. (2008). The role of conservation agriculture in sustainable agriculture. Philosophical Transactions of the Royal Society of London B: Biological Sciences 363: 543555

Ismail, I., Blevins, R. L. and Frye, W. W. (1994). Long-term no-tillage effects on soil properties and continuous corn yields. Soil Sci. Soc. Am. J. 58: 193-198.

Jackson, M.L. (1973). Soil Chemical Analysis Prentice Hall India Pvt. Ltd., New Delhi. 498

Jat, M. L.,Malik, R.K., Saharawat, Y.S., Gupta, R. 
Bhag, M., and Raj Paroda. (2012). Proceedings of Regional Dialogue on Conservation Agricultural in South Asia, New Delhi, India, APAARI, CIMMYT, ICAR, Pp 32.

Jat, R. A., Wani, S. P. and Sahrawat, K. L. (2012). Conservation agriculture in the semi-arid tropics: prospects and problems. Adv. Agron. 117: 191-273.

Kristensen, H.L., McCarty, G. W. and Meisinger, J. J. (2000). Effects of soil structure disturbance on mineralization of organic soil nitrogen. Soil Sci. Soc. Am. J. 64:371378.

Kumar B, Gupta RK, Bhandari AL. (2008) Soil fertility changes after long-term application of organic manures and crop residues under rice-wheat system. Journal of the Indian Society of Soil Science. 56: 80-85.

Lahmar R. (2008). Adoption of Conservation Agriculture in Europe- Lessons of the KASSA project. Land Use Policy 27: 4-10.

Martin-Rueda, I., Muñoz-Guerra, L. M., Yunta, F., Esteban, E., Tenorio, J. L. and Lucena, J. J. (2007) Tillage and crop rotation effects on barley yield and soil nutrients on a Calciortidic Haploxeralf. Soil and Tillage Research 92, 1-9.

Matos ES, Freese D, Mendonca ES, Slazak A, Huttl RF. (2011) Carbon, nitrogen and organic $\mathrm{C}$ fractions in topsoil affected by conversion from silvopastoral to different land use systems. Agroforestry Systems. 81:203-211.

Obour A. K., Mikha M. M., Holman J. D. and Stahlman P. W. (2017). Changes in soil surface chemistry after fifty years of tillage and nitrogen fertilization. Geoderma. 308:46-53.

Olsen, S.R., Cole, C.V., Watanabe, F.S., and Dean, L.A. (1954). Estimation of available phosphorus in soils by extraction with sodium bicarbonate. Gov. Printing Office Washington D.C. USDA Circular. 939:119.

Paustian K, Collins HP, Paul EA. (1997) Management controls on soil carbon. (eds. Paul E.A., Elliott E.T, Paustian K., Cole C.V.), Soil organic matter in temperate agroecosystems: long-term experiments in North America. CRC Press, Boca Raton,
FL, 15-49.

Peng KJ, Luo CL, You WX, Lian CL, Li XD, Shen ZG (2008) Manganese uptake and interactions with cadmium in the hyper accumulator-Phytolacca. Americana L. J. Hazard Matter., 154:674-681.

Roldán A, Salinas-García JR, Alguacil MM, Caravaca F (2007) Soil sustainability indicators following conservation tillage practices under subtropical maize and bean crops. Soil and Tillage Research, 93(2): 273-282.

Sarkar, M. C., Sachdev, M. S., and Datta, S. P. (1998) Interaction of soil organic matter with nutrients. Bull. Indian Soc. Soil Sci. 19, 90-102.

Sharma RP, Roy RK, Jha CB (1988) Production potential and economics of rice-wheat sequence as influenced by organic and inorganic fertilizer. Annals of Agricultural Research, 9:280-283.

Shear, G. M. and Moschler, W. W. (1969). Continuous corn by the no-tillage and conventional methods. Agron. J. 61: 524526.

Sidhu, H.S., Singh, M., Humphreys, E., Singh, Y., Singh, B., Dhillon, S. S., Blackwell, J., Bector, V. M., and Singh, S. (2007) The happy seeder enables direct drilling of wheat into rice straw. Australian Journal of Experimental Agriculture, 47, 844-854.

Singh, Y. and Ladha, J. K. (2004). Principles and practices of tillage system in rice-wheat cropping system in Indo-Gangetic plains of India. pp 167-207. In. Lal, R., P. R. Hobbs, N. Uphoff and D. O. Hansen, Ed. Sustainable agriculture and the international rice-wheat system. Marcel Dekker, Inc., New York.

Subbiah, B.V., and Asija, G.L. (1956). A rapid procedure for the estimation of available nitrogen in soils. Current Science. 25: 259266.

Tandon, H.L.S. (1991). Sulphur research and agricultural production in India. $3{ }^{\text {rd }}$ ed. The Sulphur Institute, Washington, D.C.

Thierfelder, C. and Wall, P.C. (2009). Effects of conservation agriculture techniques on infiltration and soil water content in Zambia and Zimbabwe. Soil and Tillage Research. $105,217-227$. 
Thierfelder, C., Mwila, M. and Rusinamhodzi, L. (2013). Conservation agriculture in eastern and southern provinces of Zambia: Longterm effects on soil quality and maize productivity. Soil and Tillage Research. 126, 246-258.

Thomas, G. A., Dalal, R. C. and Standley, J. (2007). No-till effects on organic matter, $\mathrm{pH}$, cation exchange capacity and nutrient distribution in a Luvisol in the semi-arid subtropics. Soil and Tillage Research 94: 295-304.

Triplett, G. B. and Van Doren, D. M. (1969). Nitrogen, phosphorus and potassium fertilization for non-tilled maize. Agron J. 61: 637-639.

Van Wie, J.B., Adama, J.C. and Ullman, J.L. (2013). Conservation tillage in dryland agriculture impacts watershed hydrology. Journal of Hydrology. 483, 26-38.

Verhulst, N., Govaerts, B., Verachtert, E., Navarrete, A. C., Mezzalama, M., Wall, P., Deckers, J. and Sayre, K. D. (2010). Conservation agriculture, improving soil quality for sustainable production systems? In: Lal, R., Stewart, B.A. (Eds.), Advances in Soil Science: Food Security and Soil Quality. CRC Press, Boca Raton, FL, USA, pp. 137-208.

Walkley, A., and Black, C.A. (1934). An examination of wet acid method for determining soil organic matter and a proposed modification of the chromic acid titration method. Soil Science. 37: 29-38.

Wall, P.C. (2007). Tailoring conservation agriculture to the needs of small farmers in developing countries: An analysis of issues. Journal of Crop Improvement 19:137-155

Wang, Q., Bai, Y., Gao, H., He, J., Chen, H., Chesney, R.C., Kuhn, N.J. and Li, H. (2008). Soil chemical properties and microbial biomass after 16 years of notillage farming on the Loess Plateau, China. Soil and Tillage Research 144: 502-508.

Wang, Y.L., Li, J. (2014). Study of tillage patterns suitable for soil physicochemical properties and crop yields in wheat /maize fields. Am. J. Plant Nutr. Fertil. Technol.20, 11391150 .

Yadav BK, Sidhu AS, Thaman S (2016) Soil fertility status of Punjab Agricultural University seed farm, ChakRuldu Singh Wala, Sangat, Bathinda, Punjab. Annals of Plant and Soil Research, 18:226-231. of conservation tillage and nutrient management practices on soil fertility and pro

Yadav G. S., Datta R., Pathan S. I., Lai R., Meena R. S., Babu S., Das A., Bhowmik S. N., Datta M., Saha P. and Mishra P. K. (2017). Effects productivity of rice (Oryza sativa L.)-rice system in north eastern region of India. Sustainability. 9:1816-1832.

Yadav MR, Parihar CM, Kumar R, Yadav RK, Jat SL, Singh AK, Ram H, Meena RK, Singh $M$, Meena VK, Yadav N, Yadav B, Kumawat C, Jat ML (2017) Conservation Agriculture and Soil Quality- An Overview. Int.J.Curr.Microbiol.App.Sci., $\quad 6(2)$ :707734.

\section{How to cite this article:}

Dipti Kumari, Sunil Kumar, Hena Parveen, Amit Kumar Pradhan, Sanjay Kumar and Ragini Kumari. 2019. Long-Term Impact of Conservation Agriculture on Chemical Properties of Soil. Int.J.Curr.Microbiol.App.Sci. 8(07): 2144-2153. doi: https://doi.org/10.20546/ijcmas.2019.807.258 